\title{
Religious Leaders' Knowledge of Family Planning and Modern Contraceptive Use and Their Involvement in Family Planning Programmes in Burkina Faso: A Qualitative Study in Dori in the Sahel Region
}

\author{
Abibata Barro' \\ Aristide Romaric Bado (D) 2,3 \\ 'Service de formation des sages-femmes \\ et maïeuticiens, École Nationale de Santé \\ Publique (ENSP), Koudougou, Burkina \\ Faso; ${ }^{2}$ Département Biomédical et Santé \\ Publique, Institut de Recherche en \\ Sciences de la Santé, Ouagadougou, \\ Burkina Faso; ${ }^{3}$ Demography and Sexual \\ and Reproductive Health Project \\ (DEMSAN), Organisation Ouest \\ Africaine de la Santé (OOAS), Bobo- \\ Dioulasso, Burkina Faso
}

Introduction: It is necessary to understand religious leaders' perceptions of modern contraceptive use and their role in influencing fertility behaviour for the successful adoption of family planning, especially in societies where the religious leaders' opinions can have a significant influence on individuals' reproductive decisions. This study, therefore, aimed to assess religious leaders' knowledge of family planning and their involvement in family planning programmes in the Sahel region of Burkina Faso.

Methods: This is a qualitative study comprising in-depth individual interviews with twenty-one religious' leaders in the town of Dori in the Sahel region of Burkina Faso. An interview guide was used for data collection. This interview guide was developed based on the central themes and sub-themes determined for the research, namely, the religious leaders' knowledge of modern contraception, the inclusion of information on modern contraception during religious activities and the relationship between religious leaders and reproductive health services. All interviews were recorded and transcribed in French using Microsoft Word. The verbatims were then coded for content analysis. The analysis method chosen was that of thematic analysis.

Results: The results of the study showed that religious leaders had good knowledge about family planning including modern contraceptive methods and fertility regulation through birth spacing. Regarding their involvement in family planning programme, religious leaders said they were not involved enough. However, the results of the study showed that leaders are reluctant to promote the use of FP methods.

Conclusion: Although religious leaders are knowledgeable about family planning, they are still reluctant to promote the use of modern contraceptive methods in their communities. To do so, efforts are needed to sensitise and mobilise them in family planning programmes. The cooperation of local religious leaders will help promote family planning and improve Burkina Faso's performance on the Sustainable Development Goals through the achievement of the demographic dividend in the country.

Keywords: religious leaders, family planning, knowledge, involvement, Sahel region, Burkina Faso

\section{Introduction}

With an estimated population of 401 million in 2020 (37\% of the population of subSaharan Africa (SSA)), West African countries are characterised by their very slow demographic and fertility transitions, resulting in rapid population growth. ${ }^{1}$ This poses significant challenges to the development prospects of these countries in
Département Biomédical et Santé

Publique, Institut de Recherche en

Sciences de la Santé, 03 BP 7192

Ouagadougou 03, Ouagadougou, Burkina

Faso

Tel +2267078338 I

Email arbado@gmail.com 
terms of having better quality of infrastructure and basic social services such as education, health and employment. With an average of more than five (5) children per woman, most countries in the region are among the countries with the highest fertility levels in the world. Burkina Faso has one of the highest population growth rates in the world (over 3\% per year) with high fertility levels supported by pro-natalist cultural values. Cultural and socio-economic factors act in concert at the societal level to determine norms concerning family size. ${ }^{2}$ Among the socio-cultural factors, religion plays an important role in shaping decisions about fertility and family planning (FP). ${ }^{3}$ As religion is specifically characterised by the development of social codes to guide human behaviour, it has been noted that several religions are characterised by their particular attention to sexuality, gender roles and the place of the family in society. ${ }^{4}$ Religion is one of the important factors that determine an individual's personal and social behaviour within their family. In most societies, religion has immense socio-cultural, economic and political significance in determining fertility. ${ }^{5}$

Extensive literature exists on the association between fertility and religion, much of which focuses on the alleged higher fertility and greater resistance to FP among Muslims and traditional religionists than among the adherents of other religions. Religion, or more precisely the religious interpretations of the local clergy, is also an important barrier to the use of modern FP methods. ${ }^{6}$ Religion exerts strong social, economic and cultural influence and plays a crucial role in the acceptance of FP. Barriers to effective contraceptive use include personal beliefs that may be shaped by both culture and religion. $5,7,8$

A possible reason for the variation in the prevalence of contraceptive use in Muslim societies could be the differences in the attitudes of religious leaders. ${ }^{9-11}$ Islam is practised under the supervision of religious leaders (most of whom are men), who form a kind of an elite group, whose entry into this position is through the religious education provided in religious schools, commonly called madrasas. The views of religious leaders carry great weight and profoundly influence the views of those studying in the madrasas and, through them, the behaviour of the general population. ${ }^{12}$ It should not be assumed that religious leaders in Muslim countries are invariably conservative, as this hinders the dissemination of positive views on FP among the general population. ${ }^{3}$ In Ethiopia, for instance, Islam (the religion of the Muslims) is the most important source of information on FP. A study carried out in Ethiopia had found that Islam was the main contextual factor that influenced FP acceptance in the community that was studied. The perceptions and beliefs of the religious leaders can a powerful force. Preventing pregnancy in women was seen as a direct opposition to religious principles, especially Islam. As per Islamic religious beliefs, birth prevention is haram (forbidden) under the Islamic law ${ }^{12}$ which is a barrier to the use of FP.

Previous studies have shown that religious leaders are important opinion leaders. They have a strong influence on communities and can play a key role in informing the community about fertility behaviour, the use of contraception and FP. ${ }^{7,8,13-15}$ Studies in African countries have shown that religious leaders have the power to either inhibit or facilitate the actual adoption of behaviour in favour of contraceptive use, choosing the number of children to have and FP. ${ }^{16}$ Underwood's study ${ }^{13}$ in Jordan and Population Services International's ${ }^{15}$ in Niger found that religious leaders were less supportive of FP and the use of modern contraceptive methods and claimed that modern contraception had negative side effects. Religious leaders in Islamic societies are often concerned that FP methods are used to limit family size, which is not in accordance with Islam. ${ }^{8}$ In Niger, religious leaders are divided on the issue of FP. Those who support it are not willing to preach on the benefits of contraception in public. ${ }^{15}$ Krishnaratne et al showed that, in Ethiopia, the acceptability of FP by religious leaders was a key factor that led to greater community acceptability, which in turn influenced women's decisions about FP. ${ }^{12}$ Acceptance of FP by religious leaders was triggered by their ability to see that FP aligned with their religious beliefs. Knowing that they did not have to adjust or compromise their religious beliefs to support FP was what led to its acceptance among religious leaders. ${ }^{12}$ Similarly, Azmat et $\mathrm{al}^{16}$ found that religious leaders in Pakistan too had a strong influence on communities and could play a key role in informing the community about the benefits of FP. Acceptance of FP by religious leaders in this context was influenced by exposure to FP messages and information from health professionals. ${ }^{12}$ The Nigerian study found a significantly higher rate of contraceptive use among women who had been exposed to FP messages from religious leaders than among those who had not. ${ }^{16,17}$

A study in Malawi examined the role of religious leaders, who were generally supportive of organizing such 
events in their communities, especially in terms of learning about the benefits of FP and disseminating this information to their congregations. ${ }^{17,18}$ In general, the involvement of religious leaders in FP messages has had positive results. ${ }^{17}$ This study further found that religious leaders' message was a predictor of modern contraceptive use. It can be observed here that advocacy, demand creation and media coverage with the involvement of different important stakeholders such as religious leaders improve the use of FP methods. ${ }^{17}$

In Burkina Faso too, religious leaders play a major role in approving or disapproving the use of FP in communities. To date, there is lack of information about the opinions of Burkinabé religious leaders regarding the use of FP methods and fertility preferences. Access to and use of FP and other RH services are still low, whereas high levels of poverty, illiteracy and numerous cultural and religious beliefs constitute barriers to the provision of $\mathrm{RH}$ services to women of reproductive age. Research is therefore needed to understand religious leaders' perceptions of modern contraception and their role in influencing fertility behaviours and FP uptake, particularly in those societies where their views can have a significant influence on individuals' reproductive decisions. As in many countries around the world, Burkina Faso too has endorsed the Programme of Action of the 1994 United Nations International Conference on Population and Development, the 2000 Millennium Development Summit Declaration and the 2015 Sustainable Development Goals (SDGs) all of which call for universal access to FP information and services. ${ }^{19}$

This study, therefore, aimed to measure religious leaders' knowledge of FP and their involvement in FP programmes in the town of Dori in the Sahel region of Burkina Faso.

\section{Methods}

\section{Background to the Study}

Burkina Faso had a population of $20,487,979$ according to the preliminary results of the 2019 general population census. $^{20}$ This population is predominantly young, with average and median ages of 21.8 and 15.5 years respectively, while life expectancy at birth in 2006 was 56.7 years. $^{21}$

According to the 2003 and 2010 Demographic and Health Surveys (DHS), fertility levels have declined from $6.2^{22}$ to $6.0^{23}$ children per woman but are still among the highest in the world. The rate of use of modern contraceptive methods among women in union, which was $15 \%$ in $2010^{23}$ has nevertheless increased to $30.7 \%$ in $2018^{24}$ but barriers exist at several levels that limit the use of health services and family planning.

Dori, the capital of the Sahel region, is located $271 \mathrm{~km}$ from the capital (Ouagadougou) on National Road No. 3, which is paved. Data from the last General Census of Population and Housing of 2006 indicates that the Commune of Dori had 23,267 households spread over 78 villages and 8 sectors, and its total estimated population was 106,808. The Peulhs comprise the majority group accounting for $70.1 \%$ of the total estimated population. The other groups are Mossi (8\%), Sonrhaï (5.5\%), Gourmantché (3.6\%), Djerma (3\%) and Bella $(2.5 \%) .^{21}$ An overwhelming majority (90.7\%) of this population is Muslim. Catholics and Protestants represent 5.5\% and $3.8 \%$ respectively. ${ }^{21}$ The rate of use of modern contraception in the Sahel region is one of the lowest $(7 \%)$ compared to $15 \%$ at the national level. ${ }^{23}$

\section{Study Population}

The study population was the religious leaders in the urban commune of Dori. These leaders are the members of the Union Fraternelle des Croyants (UFC) who participate in health promotion activities. They were in a position to provide us with information on their activities, their communication strategy and the obstacles they have encountered in the implementation of health promotion activities in Dori. It was suggested to them that they can make recommendations in view of the findings of this study. UFC, in Dori, is an interdenominational association that came into being during the turmoil of the famine of 1969 thanks to the impetus provided to it by Reverend Father Lucien BIDAUD. Ever since, it has been an example of inter-religious dialogue and an instrument of socioeconomic development. $^{25}$

\section{Sampling}

Twenty-one religious leaders were sampled using the following procedure: To have all the categories of people in our target population duly covered, we reached out to UFC. We identified the various religious leaders in the different districts of the urban commune of Dori with the help of the UFC's Executive Secretary.

We proceeded with a purposive sampling with maximum variation. The principle of maximum variation was adopted to explore as much diversity concerning the subject matter as possible. The diversification, as sought, was 
achieved through recruiting male and female respondents and from different religions for the study. Further, internal diversity within these categories was also taken into account in terms of age, place of residence and educational attainment. Each respondent was considered a key informant and bearer of a subsystem of values. Thus, on the whole, the respondents had different levels of education, they included both elderly and adult persons in the urban commune of Dori.

\section{Data Collection}

An interview guide was used for data collection. This interview guide developed based on the central themes and subthemes of this research, namely, the religious leaders' knowledge of modern contraception, the inclusion of information on modern contraception during religious activities, and the religious leaders' relationship with RH services.

The interviews took place from 3rd to 9th September 2018 and were conducted by the principal investigator of the study as part of their master's thesis in public health. The interviews took place at the homes or workplaces of the respondents, and they were recorded using a dictaphone.

\section{Data Analysis}

The interviews were transcribed first to create a usable database. All interviews were transcribed verbatim on Word without attempting to rephrase what the respondents said. The analysis method that was chosen was thematic analysis. After the transcription was done, the data was coded. Braun and Clarke's thematic analysis model as used, ${ }^{26}$ which is a six-step analysis that involves the research team familiarising itself with the transcribed data, coding of the interviews, defining the themes, and making groupings/ categories before writing down the findings/results. The coding of the data was done manually. In the analysis phase, the data was classified as a unit of meaning the constituting themes. The work consisted of identifying the nuclei of meaning contained in the text whose presence and frequency was significant. The responses during the interviews were categorised into several main themes and subthemes to allow a precise description of their content. This division focused on meaning rather than form as it related to the level of analysis.

\section{Ethical Considerations}

The protocol proposed for this research was submitted for approval to the Ethics Committee for Health Research in
Burkina Faso. The permission of the National Ethics Committee was obtained vide deliberation N 2018-7-095 dated 19th July 2018. Before carrying out the field survey, the IFRISSE management sent an authorisation request to the Regional Director of Health of the Sahel, dated 05 June 2018 for permission to collect data as proposed in the study's methodology. In response to the request, a survey authorisation (N 2018-084/MS/RSHL/DRS of 12th June 2018) was issued by the authority concerned.

Further, verbal informed consents of the participants who decided to participate in this study were obtained without any coercion whatsoever. The verbal informed consent form was previously approved by the National Ethics Committee for Health Research in Burkina Faso. No identification information was linked to the interviews or retained after the analysis was completed. The participants were guaranteed confidentiality of the information collected from them. All the participants were informed about the purpose of the study, which was done in accordance with the Helsinki Declaration, and their consented was also sought for the anonymously publishing the responses and quotes.

\section{Results}

\section{Description of the Participants}

As for their socio-demographic profile, the respondents comprised nine (9) women and twelve (12) men (Table 1). Their ages ranged from 37 to 78 years, with an average age being around 45 years. Three participants had had primary education, ten of the participants had had secondary education and eight had had tertiary education. Eight participants were Muslims, seven were Roman Catholic and six were Protestants. The participants are spread over the five sectors of the Dori urban commune.

\section{Religious Leaders' Knowledge of FP and Modern Contraceptive Methods}

The analysis identified four sub-themes regarding leaders' knowledge of FP. These sub-themes were: knowledge of birth control, knowledge of modern contraceptive methods, knowledge of harnessing the demographic dividend and knowledge of the relationship between religion and modern contraceptive practice.

\section{Knowledge of Family Planning}

The analysis of the interview data shows that the religious leaders see birth control as a necessity. They also argued that there is no contraindication to birth control, as evidenced by the statement: "Absolutely! It is useful to 
Table I Socio-Demographic Profile of Religious Leaders

\begin{tabular}{|l|l|l|l|}
\hline $\begin{array}{l}\text { Socio-Demographic } \\
\text { Characteristics }\end{array}$ & N & $\%$ \\
\hline Gender & Male & 12 & 57.1 \\
& Female & 9 & 42.9 \\
\hline Age & Below-40 years & 2 & 9.5 \\
& $40-59$ years & 15 & 71.4 \\
& 60 and above & 4 & 19.0 \\
\hline Level of education & Primary & 3 & 14.3 \\
& Secondary & 10 & 47.6 \\
& Post-secondary & 8 & 38.1 \\
\hline Religion & Catholic & 7 & 33.3 \\
& Muslim & 8 & 38.1 \\
& Protestant & 6 & 28.6 \\
\hline Area of provenance (in the city of & Sector I & 6 & 28.6 \\
Dori) & Sector 2 & 4 & 19.0 \\
& Sector 3 & 3 & 14.3 \\
& Sector I & 3 & 14.3 \\
\hline N & Sector 5 & 5 & 23.8 \\
\hline & & $\mathbf{2 1}$ & 100 \\
\hline
\end{tabular}

regulate births, because birth control is not just now". (Leader 1, Male, 53, Catholic).

The responses during the interviews showed that religious leaders value birth spacing and are aware of the negative consequences of close pregnancies for the mothers:

Because a woman every year you will give birth, it is not good. But if a woman spends two to three years before giving birth, she will feel healthy herself. She will be able to do her business, her activities, without worries to say that my child came in here, it came out. You will be in good health, you will save money. (Leader 6, Female, 37, Muslim)

\section{Knowledge of Modern Contraceptive Methods}

There is a thorough knowledge among the religious leaders of the different forms of contraceptive methods available (pills, implants and injectables) and their usefulness for birth spacing. The interview data showed that religious leaders, regardless of their education, age and religion, have a good knowledge of the modern contraceptive methods commonly used by women in the region. The methods most mentioned by the respondents are the pill, the Intrauterine Device (IUD) and the implant:

I know that we talk about the pill ... it is not new. We also talk about ... the injection, that's more recent ... We also talk about ... the IUD! The Norplant, I've seen people doing that already. (Leader 2, male, 78, Muslim)

However, despite their knowledge of the methods, an analysis of the verbatim reports revealed statements that did not support the use of modern contraceptives by women. The religious leaders did not approve of women using modern contraceptive methods because they considered them to be a birth limitation that is not tolerated by their religion. According to the respondents, modern contraceptives are an impediment to procreation, which is the result of the Creator's generosity and providence. For example, Leader 8 (Female, 49, Muslim), for whom procreation is a divine blessing, told us that:

I personally do not approve of contraceptive methods. Those that really consist in ending the life of children. The Prophet Mohamed said that he would like his whole community to be the most numerous of the communities that preceded us ... A child is a gift from God that should never be refused.

However, some religious leaders seemed to be in favour of the use of modern contraception, because it preserves the health and well-being of the mother and the child. In this regard, Leader 06 (Female, 37, Muslim) mentioned: "Really the best solution, the woman must take contraceptives for at least 3 years. You are in good shape, you are happy, the husband is happy". This was confirmed by Leader 10 (Male, 56, Protestant) in the following words:

Yes, it is very useful, for the well-being and especially the health of the family, the lady and the children ... You have to know how to multiply in a responsible way. Someone who starts to produce, you don't care about the rest. I call it production.

\section{Knowledge on Capturing the Demographic Dividend} Generally speaking, the information obtained from the participants shows their fairly good knowledge of the merits of capturing the demographic dividend. On this subject, Leader 5 (Male, 51, Muslim) related his opinion:

... the demographic dividend simply consists of promoting birth control policies that ensure good management of the resources available with the populations of the country to be managed.

This is in line with the policies that encourage family planning in the context of countries in the sub-region such as Burkina Faso. In the same vein, Leader 2 (Male, 78, Muslim) said: 
Yes, it's a good thing if it can help the person in terms of their health and their future. I think that if the State has seen fit to put it into practice, it should be for the benefit of the population and also ... the progress of the whole society.

However, some participants did not seem to agree with the importance of capitalising on the demographic dividend:

We still have to prove it. We have to prove that by reducing births we can achieve economic growth. I don't believe it! Because China and Japan are highly populated countries but at the same time well-developed. (Leader 3, Female, 42, Catholic)

On his part, Leader 7 (Male, 47, Catholic) put forward various reasons to justify his choice:

Burkina Faso currently has between 17 and 18 million. But the current territory of Burkina Faso is almost the same as Italy, that's it ... without its islands, it has 58 million inhabitants. And I think that compared to that, Burkina Faso is underpopulated. But numbers count for development. When there are enough people, development is possible. And that also allows for the control and specialisation of sectors. For the moment, I think that births are not a problem.

\section{Knowledge About the Relationship Between Religion and Modern Contraceptive Practice}

There was unanimity among all the participants that religion does not allow the use of modern contraceptive methods. They, therefore, advocated the use of natural or traditional methods to space births. Almost all the participants seem to be convinced about this being the solution. The following verbatim shows the participants' points of view in this regard:

... one can say yes that religion is an obstacle here a barrier to the use of these methods as long as one does not accept it ... We can say that the tradition in its strength in its tendency does not even know these methods and rejects them. (Leader 1, Male, 53, Catholic)

Leader 10 (Male, 56, Protestant) added:

The Christian himself advocates above all the spacing of births. Every husband must abstain so that his child grows up, as it is not the food there. You have to abstain so that the child grows up, and then his little brother will come.

Apart from the use of modern methods of spacing, some participants gave their choice of planning: “ ... I can guarantee you that the belt is $100 \%$ guaranteed. The belt that our parents applied, the woman was guaranteed against illness and pregnancy" (Leader 2, Male, 78, Muslim). In addition, Leader 3 (Female, 42, Muslim) gave examples of methods well-suited to young people:

... it really gives us the opportunity to train girls on how to know their cycle and be responsible. That's it, and I can even tell them how to naturally choose the sex of their child. And so we have created a club called the abstinence club. And so it allows us to really spread to talk more about the natural method and to speak against modern methods of contraception.

In sum, these extracts show that, in most cases, the religious leaders surveyed have correct knowledge of modern contraception and an acceptance of the relevance of capturing the demographic dividend in our country. Furthermore, it can be concluded that birth spacing is accepted by all, given its health benefits for the family, the mother and the children. All in all, the participants' rejected the modern contraceptive methods by drawing on religion and tradition and favoured natural or traditional methods and abstinence.

\section{Involvement of Leaders in FP Programmes}

The religious leaders interviewed insisted that they are not sufficiently involved in RH activities. From their replies, it could be understood that the contraceptive methods they support are not appreciated by the RH services. Moreover, these two stakeholder categories rarely get an opportunity to meet at both the national and regional levels. They only get to meet locally. Leader 2 (Male, 78, Muslim) stated:

No, I am not in touch with the reproductive health services! I have not yet participated in a meeting at the national level or in Dori. On family planning? No!!! That is, usually, they send a letter; which says good something is going to happen. It's the information letter only.

Leader 4 (Female, 38, Catholic) testified in this sense:

I haven't had the opportunity yet. I have to say that we understand each other up to a certain level where we have to help the person to know himself; we have to help the girl to be responsible. I think, maybe, they have other ways to raise awareness without going through us! Personally, no, I haven't been invited yet.

Then, Leader 5 (Male, 51, Muslim) retorted: 
No, as we are at the local level, relations are also appreciated at the level of our intervention radius at the local level as far as FP is concerned. In all the regional, provincial, communal administrations, the community has good relations with these different levels.

Many religious leaders are not involved in promoting modern contraceptive methods, and the IUD method was rejected by all study participants. Leader 3 (Female, 42, Muslim) said: "[Silence] of course, I do not participate in the promotion of these methods! [Laughs], I promote the natural method ... The IUD is about stopping pregnancies ... ". And she continued:

... There are some who have become sterile because of the use of these methods. There are also some who are no longer healthy because of this, they will end up getting cancer. (Leader 3, Female, 42, Muslim)

Leader 7 (Male, 47, Catholic) agreed with the others:

I was not involved in promoting these methods. I was approached to promote it; I read with great interest, but I want to defend the position of the Church to others. I can't get out of that position.

He added:

That's when I really understood the danger of certain methods that women don't know about but which are abortifacients. Especially since we know that these methods are not $100 \%$ safe. And the Norplant that makes them fat at random. (Leader 7, Male, 47, Catholic)

Some participants are not totally against the promotion but have reservations, such as Leader 6 (Female, 37, Muslim) and Leader 10 (Male, 56, Protestant). Here is an extract from the verbatim:

No, it is not in our nature to insert such things in the preaching. But here, there have been times when people have made us aware of these methods. We talk about this to other women in the various training sessions. Now, when you are not married, you take these things to go out with people to wander. Really, this is not good. Because it's not a necessity, you can abstain for your own respect. (Leader 6, Female, 37, Muslim)

And then "I think it's a good thing for society. At my level I find that participating in this is good work because it does society good" (Leader 10, Male, 56 years old, Protestant). However, he states that:
(...) Especially the Norplant, after they have been removed they can no longer have children, so it causes problems in the home. (...) Provided that someone does not abort and say that they are planning. (Leader 10, male, 56 years old, Protestant)

In sum, the religious leaders interviewed in the urban commune of Dori do not approve of the use of modern methods and do not promote them. The few leaders who do accept it have doubts about certain methods that they find abortifacient or infanticidal.

\section{Discussion}

This research aimed to assess religious leaders' knowledge of FP issues, modern contraceptive methods, relationship between religion and modern contraception use, and involvement of religious leaders in promoting FP.

The results of the study showed that religious leaders had a good knowledge of FP, including modern contraceptive methods and fertility regulation through birth spacing. According to the results of the Burkina Faso Demographic and Health Survey (DHS, 2010), 97\% of women and $99 \%$ of men know at least one contraceptive method. ${ }^{23}$ Since the 1990 s, there has been a lot of communication about modern contraceptive methods which has significantly improved people's knowledge. Also, through the free FP method programmes ${ }^{27}$ and the delegation of tasks in the field of family planning in Burkina Faso, ${ }^{28}$ there has been much improvement in people's knowledge of FP and the various contraceptive methods.

However, the results show that despite their good knowledge of FP, religious leaders overwhelmingly stated that the use of modern contraceptive methods is contrary to the principles of religion. Indeed, religion remains a central issue in the discourse on FP and contraception despite the diligent efforts of the government's FP programmes and the proactive advocacy carried out by nongovernmental organisations. At the International Conference on Population and Development in Cairo, in 1994, there was religious opposition to some forms of contraception and birth control. ${ }^{29}$ According to the 2006 census, more than half of the population of the region is women. Islam is by far the majority religion in Burkina Faso (60.5\% of the population). Next in order of importance is the Catholic religion (19.0\%), the animist religion $(15.3 \%)$ and the Protestant religion (4.2\%). ${ }^{21}$ In Burkina Faso' Sahel region, Muslims represent $90.7 \%{ }^{21}$ of the population. The unfavourable behaviour of religious 
leaders (mainly the followers of Islam) in the Sahel region seems to be in line with the results found in other staunchly Islamic settings. In Ethiopia, religion was the main contextual factor influencing FP acceptance in the study community, and religious leaders' perceptions and beliefs were a powerful influence in making this happen. ${ }^{12}$ Other research on this subject in West Africa $^{30}$ and Burkina $\mathrm{Faso}^{31}$ has found that religious leaders and men were barriers to using a FP methods. On the other hand, several Muslim religious thinkers have argued that, despite Prophet Mohamed's exhortation to have many children, FP is permitted and even encouraged by Islamic law. ${ }^{10,32}$ The findings of this study point to the importance of the different approaches to FP. They demonstrate the importance of individual interpretations of religious doctrine. ${ }^{33}$

During this study, Catholic religious leaders expressed opposition to the use of modern contraceptive methods as being contrary to Church doctrine. Much research has documented religious opposition to FP, with Roman Catholicism being considered the most vehement in this area. ${ }^{10}$ Indeed, since the 1960s, Pope Paul VI has been a strong opponent of modern contraceptive methods of FP, and $\mathrm{He}$ has described artificial birth control methods as immoral because they separate the two purposes of sexual relations in marriage: conjugal love and procreation of children. ${ }^{29}$ The Catholic Church opposes artificial birth control because it is a form of FP. The Catholic Church opposes all forms of modern methods and advocates periodic abstinence as the only possible contraceptive method for Catholic Christians. In 2016, in Pope Francis' Apostolic Exhortation Amoris Laetitia, other contraceptive methods, including sterilisation, were advised to be against Catholicism and described as unacceptable even in places with high fertility rates. ${ }^{34,35}$

Regarding their involvement in FP programmes, studies show that religious leaders feel that they are not involved enough. Working with religious leaders is the key to overcoming these barriers. In Bangladesh and Nepal, the involvement of Muslim religious leaders in campaigning for FP initiatives has helped to overcome barriers. In Pakistan, a predominantly Muslim country, it has been documented that it is mainly religious leaders who are against FP services and that proactively involving them in community education is extremely important for promoting contraceptive use. ${ }^{36,37}$

The involvement of religious leaders in promoting FP has enabled social mobilisation that can shift attitudes and behaviours towards those practices that are more conducive to sustainable development. ${ }^{38}$ In Bangladesh, during the early years of the FP program, there was little religious opposition to FP. Moreover, support from religious leaders came in the form of fatwas, radio and television broadcasts, editorials, mobilisation around the mosque and collaboration with the government. ${ }^{39}$ In Iran, the religious figures at the highest level supported the campaign through radio, television, newspapers and Friday prayers. Advocacy efforts were marked by an emphasis on the role of FP as essential to women's health. ${ }^{40}$ In several predominantly Muslim countries such as Jordan, Egypt and Morocco, the religious leaders have endorsed FP and contraception and, to a greater extent, believe that FP is compatible with Islam. ${ }^{40}$

\section{Conclusion}

The results of the study showed that religious leaders had good knowledge of FP, including modern contraceptive methods and fertility regulation through birth spacing. However, the results also show that despite their good knowledge of FP, religious leaders overwhelmingly stated that the use of modern contraceptive methods is contrary to the principles of religion. With regard to their involvement in FP programmes, results of our study showed that religious leaders feel that they are not involved enough. Therefore, more efforts are needed to mobilize and involve religious leaders in FP and reproductive health programmes so that they can sensitize communities on these issues and thus increase the utilization of services. The cooperation of local religious leaders will contribute significantly to the promotion of FP and the achievement of the demographic dividend.

\section{Funding}

No funding was secured for this research.

\section{Disclosure}

The authors report no conflicts of interest in this work.

\section{References}

1. Population Reference Bureau. Fiche De Données Sur La Population Mondiale. Washington, DC: Population Reference Bureau; 2020.

2. Caldwell JC. Theory of Fertility Decline. Academic Press; 1982.

3. Nasir JA, Hinde A. Factors associated with contraceptive approval among religious leaders in pakistan. J Biosoc Sci. 2011;43 (5):587-596. doi:10.1017/S0021932011000216

4. González López G. La religion et l'usage des méthodes contraceptives au Mexique. Université Sorbonne Paris Cité; 2016.

5. Marchin A, Seale R, Sheeder J, Teal S, Guiahi M. Integration of catholic values and professional obligations in the provision of family planning services: a qualitative study. JAMA Netw open. 2020;3(10): e2020297. doi:10.1001/jamanetworkopen.2020.20297 
6. Azmat SK, Ali M, Ishaque M, et al. Assessing predictors of contraceptive use and demand for family planning services in underserved areas of Punjab province in Pakistan: results of a cross-sectional baseline survey. Reprod Health. 2015;12(1):1-10. doi:10.1186/ s12978-015-0016-9

7. Guiahi M, Teal S, Kenton K, DeCesare J, Steinauer J. Family planning training at Catholic and other religious hospitals: a national survey. Am J Obstet Gynecol. 2020;222(3):273.e1-273.e9. doi:10.1016/j.ajog.2019.09.012

8. Egeh AA, Dugsieh O, Erlandsson K, Osman F. The views of Somali religious leaders on birth spacing - a qualitative study. Sex Reprod Healthc. 2019;20(February):27-31. doi:10.1016/j.srhc.2019.02.003

9. Arjyal A, Joshi D, Maharjan U, et al. Access to family planning services by Muslim communities in Nepal - barriers and evidence gaps. 2016.

10. Arousell J, Carlbom A. Culture and religious beliefs in relation to reproductive health. Best Pract Res Clin Obstet Gynaecol. 2016;32:77-87. doi:10.1016/j.bpobgyn.2015.08.011

11. Haider S, Todd C, Ahmadzai M, et al. Childbearing and contraceptive decision making amongst afghan men and women: a qualitative analysis. Health Care Women Int. 2009;30(10):935-953. doi:10.1080/07399330903052129

12. Krishnaratne S, Hamon JK, Hoyt J, et al. What mechanisms drive uptake of family planning when integrated with childhood immunisation in Ethiopia? A realist evaluation. BMC Public Health. 2021;21 (1):1-13. doi:10.1186/s12889-020-10114-8

13. Underwood C. Islamic precepts and family planning: the perceptions of Jordanian religious leaders and their constituents. Int Fam Plan Perspect. 2000;26(3):110-117. doi:10.2307/2648299

14. Underwood C, Kamhawi S, Nofal A. Religious leaders gain ground in the Jordanian family-planning movement. Int $J$ Gynecol Obstet. 2013;123(SUPPL.1):e33-e37. doi:10.1016/j.ijgo.2013.07.006

15. Population Services International. Accroître Le Soutien Aux Activités de Santé Reproductive Parmi Les Leaders Religieux Au Niger. Vol 1. Niger; 2017. Available from: https://www.google.com/ url sa $=$ t\& $r \mathrm{t}=\mathrm{j} \& \mathrm{q}=\&$ esrc $=\mathrm{s} \&$ source $=$ web $\& \mathrm{~cd}=\& \mathrm{cad}=\mathrm{rja} \& \mathrm{uact}=$ $8 \& \mathrm{v}$ e d $=2$ a h U K E w i O 1 Y r 06 _ r u A h X u z U K H U D AeQQFjABegQIAhAD\&url=https\%3A\%2F\%2Fwww.psi.org\% 2 Fwp-content $\% 2$ Fuploads $\% 2$ F $2017 \% 2$ F $11 \% 2$ FVolumeI-INSPIRATION-1-1.pdf\&usg=AOvVaw2gOBKiJO-_-XJ70b715A2. Accessed June 22, 2021.

16. Adedini SA, Babalola S, Ibeawuchi C, Omotoso O, Akiode A, Odeku M. Role of religious leaders in promoting contraceptive use in Nigeria: evidence from the Nigerian Urban reproductive health initiative. Glob Health Sci Pract. 2018;6(3):500-514. doi:10.9745/ GHSP-D-18-00135

17. Yarinbab TE, Getachew S, Kassa S, Atomsa W, Setegn M. What works in family planning interventions in Sub-saharan Africa: a scoping review. $J$ Womens Health Care. 2019;8(4):1-6. doi:10.35248/2167-0420.19.8.471

18. Lemani C, Kamtuwanje N, Phiri B, et al. Effect of family planning interventions on couple years of protection in Malawi. Int J Gynecol Obstet. 2018;141(1):37-44. doi:10.1002/ijgo.12439

19. Simelela N. Women's access to modern methods of fertility regulation. Int J Gynecol Obstet. 2006;94(3):292-300. doi:10.1016/j. ijgo.2006.04.014

20. Institut National de la Statistique et de la Démographie (INSD). Resultats Préliminaires Du 5e Recensement De La Population 2019. Institut National de la Statistique et de la Démographie (INSD); 2020

21. Institut National de la Statistique et de la Démographie (INSD). Etat et Structure de La Population. Institut National de la Statistique et de la Démographie (INSD); 2009.

22. Institut National de la Statistique et de la Démographie/Burkina Faso. ORC Macro, Burkina Faso Enquete Demographique et de Sante 2003; 2004. Available from: http://dhsprogram.com/pubs/pdf/ FR154/FR154.pdf. Accessed June 22, 2021.
23. INSD and ICF International, Institut National de la Statistique et de la Démographie (INSD) et ICF International. Enquête Démographique et de Santé et à Indicateurs Multiples Du Burkina Faso 2010. Calverton, Maryland, USA: INSD and ICF International, Institut National de la Statistique et de la Démographie (INSD) et ICF International; 2012.

24. Institut Superieur des Sciences de la Population. Results of performance monitoring and accountability 2020, vague 6, Burkina Faso; 2018. Available from: https://www.pma2020.org/research/countryreports/burkinafaso. Accessed June 22, 2021.

25. UFC-Dori. Présentation de 1'Union fraternelle des croyants de Dori; 2021. Available from: http://www.ufc-dori.org/index.php/presenta tion/qui-sommes-nous.html. Accessed June 22, 2021.

26. Braun V, Clarke V. Using thematic analysis in psychology. Qual Res Psychol. 2006;3(2):77-101. doi:10.1191/1478088706 qp063oa

27. Bakyono R, Tapsoba LDG, Lépine A, et al. Utilisation des contraceptifs par les femmes rurales mariées ou en concubinage au Burkina Faso: une analyse qualitative de l'utilisation d'un bon gratuit. Pan Afr Med J. 2020;37(72). doi:10.11604/pamj.2020.37.72.23786

28. Kaboré S, Sanou R, Baillou B, et al. Délégation des tâches dans le domaine de la planification familiale au Burkina Faso: qualité des services offerts par le délégataire. Pan African Med J. 2020;8688:1-16.

29. Wulifan JK, Bagah DA. Male involvement in family planning in muslem communities in Wa Municipality, Ghana. Res Human Soc Sci. 2015;5(7):2225-2484.

30. Ledger ML. Sociocultural barriers to family planning and contraceptive use: evidence and interventions with a focus on West Africa. 2015.

31. Bado AR, Badolo H, Zoma LR. Use of modern contraceptive methods in Burkina Faso: what are the obstacles to male involvement in improving indicators in the centre-east and centre-north regions? Open Access J Contracept. 2020;11:147-156. doi:10.2147/OAJC. $\mathrm{S} 274570$

32. Boonstra H. Islam, women and family planning: a primer. Guttmacher Rep. 2001.

33. Hayford SR, Trinitapoli J. Religious differences in female genital cutting: a case study from Burkina Faso. J Sci Study Relig. 2011;50 (2):252-271. doi:10.1111/j.1468-5906.2011.01566.x

34. François P. Amoris lætitia. Vatican; 2016. Available from: http:// www.vatican.va/content/francesco/fr/apost_exhortations/documents/ papa-francesco_esortazione-ap_20160319_amoris-laetitia.html. Accessed June 22, 2021.

35. Greguš J. Catholicism and contraception. Ces Gynekol. 2019;84 (6):468-474.

36. Ali M, Ushijima H. Perceptions of men on role of religious leaders in reproductive health issues in rural Pakistan. J Biosoc Sci. 2005;37 (1):115-122. doi:10.1017/S0021932003006473

37. Shaikh BT, Azmat SK, Mazhar A. Lessons from Islamic countries s-68 scenarios in other Islamic countries. J Pak Med Assoc. 2013;63 (4(suppl 3)):S67-72.

38. UNFPA. Religion and Development Post-2015. In: Karam A, ed. New York, NY: UNFPA; 2014

39. Marshall K. L'engagement religieux dans les politiques de la planification familiale; 2015. Available from: https://www.google.com/url?sa= $\mathrm{t} \& \mathrm{rct}=\mathrm{j} \& \mathrm{q}=\& \mathrm{esrc}=\mathrm{s} \&$ source $=\mathrm{web} \& \mathrm{~cd}=\& \mathrm{cad}=\mathrm{rja} \&$ uact $=8 \& \mathrm{ved}=$ 2ahUKEwixmfCZlvvuAhWIyYUKHaHXBmEQFjAAegQIAxAD\&ur l=https $\% 3 \mathrm{~A} \% 2 \mathrm{~F} \% 2 \mathrm{Fs} 3$.amazonaws.com $\% 2 \mathrm{Fberkley-center \%}$ 2F151015MarshallLEngagementReligieuxPolitiquesPlanificationFamil ialeExperie. Accessed June 22, 2021.

40. Shaikh BT, Azmat SK, Mazhar A. Family planning and contraception in Islamic countries an annotated bibliography; 2012. Available from: https://www.researchgate.net/publication/236942499_Family_ Planning_and_Contraception_in_Islamic_countries_An_annotated_ bibliography. Accessed June 22, 2021. 


\section{Publish your work in this journal}

Open Access Journal of Contraception is an international, peerreviewed, open access, online journal, publishing original research, reports, reviews and commentaries on all areas of contraception. In addition to clinical research, demographics and health-related aspects, the journal welcomes new findings in animal and preclinical studies relating to understanding the biological mechanisms and practical development of new contraceptive agents. The manuscript management system is completely online and includes a very quick and fair peer-review system. Visit http://www.dovepress.com/testimonials. php to read real quotes from published authors. 